\title{
Low-Cost Scientific Exhibition: A Proposal to Promote Science Education
}

\author{
Gustavo Henrique Varela Saturnino Alves', Lucianne Fragel-Madeira ${ }^{2,3}$, \\ Thaís Varandas de Azeredo², Helena Carla Castro, 1,2,3, \\ Grazielle Rodrigues Pereirat,5, Robson Coutinho-Silva ${ }^{1,6}$
}

\author{
${ }^{1}$ Post-Graduation Program in Teaching of Biosciences and Health, PGEBS, Fiocruz, Rio de Janeiro, RJ, Brazil \\ ${ }^{2}$ Post-Graduation Program in Science and Biotechnology, PPBI, UFF, Niterói, RJ, Brazil \\ ${ }^{3}$ Post-Graduation Program in Sciences, Technology and Inclusion, PGCTIn, UFF, Niterói, RJ, Brazil \\ ${ }^{4}$ Post-Graduation Program in Science Education, IFRJ, Nilópolis, RJ, Brazil \\ ${ }^{5}$ Professional Master Course in Education, Management and Diffusion in Biosciences, UFRJ, Rio de Janeiro, RJ, Brazil \\ ${ }^{6}$ Carlos Chagas Filho Biophysics Institute, IBCCF, UFRJ, Rio de Janeiro, RJ, Brazil \\ Email: gh_alves@id.uff.br; lfragel@id.uff.br
}

How to cite this paper: Alves, G. H. V. S., Fragel-Madeira, L., de Azeredo, T. V., Castro, H. C., Pereira, G. R., \& Coutinho-Silva, R. (2020). Low-Cost Scientific Exhibition: A Proposal to Promote Science Education. Creative Education, 11, 760-782. https://doi.org/10.4236/ce.2020.115055

Received: April 18, 2020

Accepted: May 22, 2020

Published: May 25, 2020

Copyright $\odot 2020$ by author(s) and Scientific Research Publishing Inc. This work is licensed under the Creative Commons Attribution International License (CC BY 4.0).

http://creativecommons.org/licenses/by/4.0/

\begin{abstract}
Science education has emerged in recent years in view of globalization, new jobs and demands for sustainable development as provided by the United Nations on the 2030 agenda, through the Sustainable Development Goals (SDGs). Active teaching methodologies such as STEAM emerge as a facilitator and attractive for the learning process. However, for many developing countries, the high cost prevents implementation of this methodology in formal educational settings. Thus, thinking about new, low-cost science education strategies that can supply such demand is a priority issue for the SDGs to be reached in these locations. The objective of this work was to identify the potential propagator of itinerant scientific exhibitions, with low-cost interactive activities and based on the STEAM methodology, and their evaluation by the public, aiming to achieve the goals of the SDGs. With an investment of less than three dollars per capita, Science Under Tents organized and carried out scientific exhibitions throughout its 6 years of existence in various locations in the state of Rio de Janeiro. During this time, we produced 30 interactive activities at low cost, most of which are easy and medium to reproduce and based on STEAM, in addition to addressing various aspects of the SDGs. The exhibitions were mediated by undergraduate and graduate students from several higher education institutions, who were responsible for the dialogue with the visiting public. Despite the low cost invested, exhibition was very well evaluated by the public served. Thus, we believe that itinerant scientific exhibitions, with low cost activities and based on STEAM, are interesting scientific education strategies to promote the SDGs.
\end{abstract}




\section{Keywords}

STEAM, Science Center, Travelling Museum, Sustainable Development Goals, Mediator

\section{Introduction}

The United Nations, in a meeting in 2015 with representatives of 193 countries promoted the discussion and creation of strategies to eradicate the biggest problem in the world, poverty. In this context, the participating countries, including Brazil, signed the document "Transforming Our World: The 2030 Agenda for Sustainable Development" in order to establish goals for the sustainable development of all. To this end, 17 goals for sustainable development (SDGs) were outlined. All SDGs are highly relevant and interdependent, as they are linked by a nation's economic, social, cultural and structural values. However, the SDGs 4 (Quality education), 5 (Gender equality) and 10 (Reduction of inequalities) are closely linked, as they permeate education, the pillar of a society and its development, presenting itself as a bridge for its effectiveness and expansion, both in culture, in social life, as in the market and income (ONU, 2015). In this context, in particular, scientific education stands out for being associated with issues such as innovation, market creation, health, inclusion and mainly with the recognition of the world and its functioning, in line with the goals described and the SDGs.

In the mid-2000s, the concern with science education grew exponentially, leveraged by new work horizons (Silveira, 2018). In this context, methodology based on STEAM (Science, Technology, Engineering, Arts and Mathematics) is strengthened. This way of thinking and structuring scientific education uses active teaching methodologies, use of materials and equipment present in 4.0 industry (such as 3D printers, robots, arduine) and artistic and social strategies, such as reflection on the social and community problems as well as the aesthetic sense (Conner et al., 2017). The interdisciplinarity inherent to STEAM's thinking and methodology leads both the learner and educator to value more the learning process. This process induces a reflection on solutions for society, being them environmental, health, construction or leisure. In addition, it also promotes prototyping and development of such solutions (Wang et al., 2018).

However, many of the resources associated with STEAM's methodology are expensive (Wang et al., 2018), worsening in developing countries. Thus, thinking about low-cost strategies that can supply such demand is a priority issue for the SDGs to be reached in these locations. Especially after the pandemic of COVID-19, in which the world is preparing for large-scale economic impacts (UN, 2020).

Thinking about science teaching materials at low cost is a constant practice in the reality of the classroom of several teachers. Regardless of whether it is in de- 
veloped or developing countries, the main issue is to systematize this practice so that it is efficient in these very different realities (Beyleveldt, Burnett, \& Hollander 2004; Correa et al., 2020; Hume et al., 2014; Rodrigues, Marques, \& Carvalho, 2016; Srinivasan et al., 2013). In addition, formal education has budgetary limitations, especially in developing countries such as Brazil, making priority investment in STEAM actions difficult (OECD, 2019). Thus, non-formal education spaces such as science centers and museums, in addition to leisure and entertainment, can also serve as an instrument to science education (Paula, Pereira, \& Coutinho-Silva, 2019).

In general, science centers and museums have exhibitions focused on themes and way of working of the STEAM methodology and their different approaches provide various experiences and learning opportunities. Science and art actions are a worldwide reality, as fruits not only in technical production, but also in academic productions of great relevance, including in Brazil (Almeida et al., 2018; Araújo-Jorge et al., 2018; Oppenheimer, 1972; Pugh \& Girod, 2007; Rocha \& Venturelli, 2018; Silveira, 2018; Silveira, Malina, \& Lannes, 2018).

According to McManus (1992) and Wagensberg (2001), classically science centers and museums are dedicated to scientific topics in so-called "hard" areas, such as astronomy, medicine, geology, physics, biology, chemistry, mathematics, engineering. However, their activities and exhibitions have always sought to promote dialogue with the humanities such as sociology, museology, cultural production, expography, art and anthropology, among others (Loureiro, 2009; Murriello, Contier, \& Knobel, 2018). Such relationships become even more expressive and valuable in the systematization of STEAM and intertwine, not only the exact areas, but also the human ones with a view to presenting the world, nature and human solutions.

However, science and technology area, especially science communication, lacks investments, mainly in developing countries such as Brazil (Klebis, 2018). Reality that directly affects science centers and museums, classic space for science communication. It should also be considered that logistics for public participation in these spaces, especially school audience, is also a costly process, lacking transportation, food and temporal organization (Cazelli, Falcão, \& Valente, 2018). In this context, the Guides of Science Centers and Museums demonstrated an increase in roaming actions (Almeida et al., 2015; Brito, Ferreira, \& Massarani, 2005; Massarani, Brito, \& Ferreira, 2009) and these are strengthened as demands from society and governance means seek actions aimed at sustainable development and equity of opportunities, especially learning.

Traveling scientific exhibitions reduce costs for schools and increase the chances of learning STEAM topics. In addition to reducing travel costs, exhibitions at schools provide a larger number of students to be contemplated and have the same learning opportunities (Alves, 2016). Besides that, itinerant exhibitions can be planned and assembled with low cost materials and with few human resources, as long as these human resources are specialized, such as graduates or postgra- 
duates in the fields of STEAM or education. In general, itinerant exhibitions, although less costly, require a greater routine of maintenance and surveillance (Alves, 2016; Alves et al., 2019; Nascimento, Fragel-madeira, \& Alves, 2018).

Therefore, traveling exhibitions under the STEAM perspective with low-cost materials can be considered a promising instrument of scientific education, which can be systematized and exported to several countries in order to provide quality scientific education, in different environments and socio-cultural realities. The objective of this work was to analyze an itinerant science exhibition seeking to identify elements related to STEAM methodology, at low cost of its execution and that could be correlated with SDGs 4, 5 and 10 of the 2030 agenda.

\section{Methodology}

\subsection{Research Environment}

The field of research development was based on the routine of Sciences under Tents (from portuguese Ciências Sob Tendas, CST), an itinerant science center founded within the Fluminense Federal University, in Rio de Janeiro, Brazil.

CST exhibition is based on three ways of interactivity as described by Wagensberg (2001): manual interactivity or provocative emotion (Hands On), mental interactivity or intelligible emotion (Minds On) and cultural interactivity or cultural emotion (Heart On). These characteristics enable classify CST as a science center of third generation as defined by McManus (1992) "The third generation emphasis is usually on contemporary science or technology and they use interactive exhibits requiring visitor thought and manipulation as vehicles for communication."

The entire exhibition is set up under articulated tents that together form an area of $100 \mathrm{~m}^{2}$. This is considered a satisfactory area for attending up to 150 people per hour. The activities are presented on tables together with mediators who exchange knowledge present in the activities with the public. For integral attendance of public, activities are thought and developed considering different characteristics that can be presented such as: age, local culture, traditional knowledge, special needs, among others. In addition, CST mediators receive training on scientific knowledge presented in the activities, as well as on the means of communication and speech adaptation to the public (Alves et al., 2019).

Mediators are, in general, students from different undergraduate courses at fluminense universities. The mediators are linked to the CST in three ways: Volunteers-the students only participate on the day of the exhibition, willing to act in the mediation of activities and for that they receive a declaration with the workload developed; Extensionists-undergraduate students use a curricular discipline to participate in CST activities and thus complement their undergraduate curriculum; and Scholarship holders-outstanding students are identified through public selection who will contribute to the organization of CST and, for this, will receive scholarships from different funding agencies. The workload of these students is 12 hours per week. 
The activities of CST exhibition are organized under four thematic axes: Health, Nature, Technology and Humanities (Table 1). In this organizational perspective, areas of STEAM are contemplated. It is worth mentioning that many of the activities may be inserted in more than one thematic axis due to their interdisciplinary character, in addition to being susceptible to human mediation, which allows a broad spectrum of approach to themes (Alves et al., 2019).

\subsection{Survey Data}

Research data was based on two types of data collection:

1) Documentary research, in which information was sought that could support the research's main issues, such as financial resources, number of exhibitions carried out, public attended and data collected during the exhibitions.

To this end, CST data on fundraising were analyzed based on a search in the Lattes curriculum basis of the director of CST, on different sites of Brazilian development institutions (National Council for Scientific and Technological Development, Carlos Chagas Filho Foundation for Research Support of the State of Rio de Janeiro, Coordination for the Improvement of Higher Education Personnel, Fluminense Federal University). It was also carried out an analysis of internal reports of organizational activities, such as mediator registration forms and requests for visits, accountability reports and CST's scientific publications. Mediator's registration form collects data from mediators such as age, undergraduate course, motivation to participate in CST among others. And requesting exposition form collects data from institutions that wish to receive CST's exhibition such as location, type of audience, infrastructure, and so on.

All data collected followed thematic analysis criteria proposed by Fontoura (2011), seeking to identify and classify the information necessary for the research. The thematic analysis applied to analyzed documents sought to identify two important units for carrying out the thematization: units of contexts (broader texts) and units of meaning (specific terms and information). The units of meaning

Table 1. Thematic axes of science under tents activities and their activities.

\begin{tabular}{|c|c|c|}
\hline Thematic axes & Description & Example of activities \\
\hline Health & $\begin{array}{l}\text { addresses topics related to the human body, its physiology, nutritional demands, } \\
\text { diseases and well-being }\end{array}$ & $\begin{array}{l}\text { Anatomy, Microscopy, Food pyramid, } \\
\text { Knowing your cells }\end{array}$ \\
\hline Nature & $\begin{array}{l}\text { addresses topics from large areas of knowledge such as physics, chemistry, biology, } \\
\text { mathematics in general activities that aim to present and explore issues of } \\
\text { the environment and everyday life }\end{array}$ & $\begin{array}{l}\text { Solar cooker, Sprouting paper, Arthropods, } \\
\text { Electroconductivity, Pantograph }\end{array}$ \\
\hline Technology & $\begin{array}{l}\text { mainly addresses themes of new technologies associated with the use of digital } \\
\text { devices focusing on experiences and building knowledge and solutions for } \\
\text { day-to-day }\end{array}$ & $\begin{array}{l}\text { Virtual Reality, 3D Printing, Attention and } \\
\text { Movement, Augmented Reality, Robotic } \\
\text { Programming }\end{array}$ \\
\hline Humanities & $\begin{array}{l}\text { addresses issues in the humanities such as arts, history, letters and Inclusion, } \\
\text { aiming above all to keep human relations and culture alive }\end{array}$ & $\begin{array}{l}\text { Braille, Puppet theater, Painting the body, } \\
\text { LIBRAS (Brazilian Sign Language) }\end{array}$ \\
\hline
\end{tabular}


findings were grouped into themes in a coherent and cohesive manner, thus making it possible to guide theoretical analysis intended in the different research objectives. For example: Call CNPq/MCTIC No. 09/2019 National Week of Science and Technology-SNCT 2019: Context unit-name of director of CST-Universidade Federal Fluminense-global value of the concession: $\mathrm{R} \$ 90,000.00$; Unit of meaning- $\mathrm{R} \$ 90,000.00$. In this case, the unit of meaning was grouped under the theme: Resources received by CST.

2) Participant observation, which consists on researcher's participation in the process where, inserted in it, observes and collects information relevant to research objective and systematizes it. It basically consists of three processes: observation, interview and archive search. In this work, observation was emphasized. It contains an element of "explanation of the specific scenario [...]; a list of participants [...]; descriptions of the participants [...]; chronology of events; descriptions of the physical scenario and all the objects within it [...]; execution descriptions [...]; records of other verbal interactions [...]." (Angrosino, 2009).

In this stage of the research, the observer researcher placed himself in the position of a member of the group, acting as mediator and organizer of CST's activities. His attitude towards the group did not intervene in mediation practices and sought to identify aspects involved in the interaction between mediator, public and activity. No conflicts of interest were identified since the observation did not interfere in practices and interactions occurred, nor did it place itself in an ethical conflict since CST's exhibitions are public and in a public environment and open to different types of social changes.

In addition, it was sought, through Free Interpretation Analysis (Anjos, Rôças, \& Pereira, 2019), to observe and describe the activities of the CST, in order to evaluate and classify them within the STEAM areas and according to their reproducibility.

The free interpretation analysis considers that the researcher's theoretical background, as well as his field observations and his interlocution between the object of study and the research objectives must be considered and supported by the literature. In this way, through systematized observations and qualitative analysis, the Free Interpretation Analysis presents itself as an innovative methodology that values human issues, especially education. Such qualitative and subjective methodologies are advantageous for research, since the exhibitions and interactions that occur within the CST are spontaneous and often more objective strategies such as interviews or questionnaires do not capture the nuances of the research.

Finally, the analysis applied to data collected sought to identify, in CST, elements that could establish a standard of compliance with the STEAM objectives, at a low cost, per capita, of its execution and that could be correlated with SDGs 4,5 and 10 of the agenda 2030 .

\section{Results and Discussion}

Based on participant observation, it was possible to register a series of information and public dialogues, which took place during the Science under Tents (CST) 
exhibitions.

The work of CST aims at popularization of science and internalization of scientific knowledge for the general public. The State of Rio de Janeiro has one of the largest academic production networks in Brazil with several public and private universities, as well as several scientific cultural devices. However, territorial distribution of these institutions is uneven, being concentrated in the state capital. Such distribution makes it difficult for people living on the outskirts and in towns far from the capital, as well as ratifying the great social inequality in Brazil (ABCMC, 2015). In this way, CST's itinerant scientific exhibitions take place in locations lacking scientific-cultural devices such as museums, science centers, parks, the botanical garden, among others, and also in places with low social development indexes, be they deprived neighborhoods in large cities , are cities far from the capital that do not have such devices.

The activities presented during the CST exhibitions used low-cost materials and dealt with STEAM themes in an interdisciplinary and interactive way as recommended by third generation science centers (McManus, 1992; Wagensberg, 2001). In addition, activities were in line with SDG 4 of the 2030 agenda-Quality education, with regard to the goals of: "Ensuring that all girls and boys complete free, equitable and quality primary and secondary education, leading to relevant and effective learning outcomes", since the exhibitions were held in public places with unrestricted access to population, even when taking place within institutions such as schools or clubs; "Ensure that all students acquire the knowledge and skills necessary to promote sustainable development, including, among others, through education for sustainable development and sustainable lifestyles, human rights, gender equality, promotion of a culture of peace and non-violence, global citizenship and valuing cultural diversity and the contribution of culture to sustainable development "such goal can be observed in the articulation of knowledge carried out between the public-activity-mediator, this relationship enables dialogues of knowledge construction that can be fertile for building such skills (ONU, 2015).

In total, thirty activities were observed briefly described below:

- Seaweed-Seaweed that can be touched and phytoplankton are presented to be observed under the microscope (Figure 1(A));

- Compared anatomy-Human, swine and rodent plastinated ${ }^{1}$ anatomical pieces are presented, which can be touched and freely manipulated (Figure 1(B));

- Arthropods-Animals from the phylum Artrophoda encrusted in resin are presented, containing representatives of the classes Arachnidae, Insecta, Chilophoda and Diplophoda (Figure 1(C));

- Biotechnology-DNA structures are presented based on a model of interlocking pieces and an origami model and a game on gene recombination (Figure 1(D));

${ }^{1}$ Plastinated pieces are part of living beings that, after being dissected, undergo plastination process that provides long-term and non-toxic preservation after process is complete. This material is used in education and science communication actions (Géra et al., 2017). 

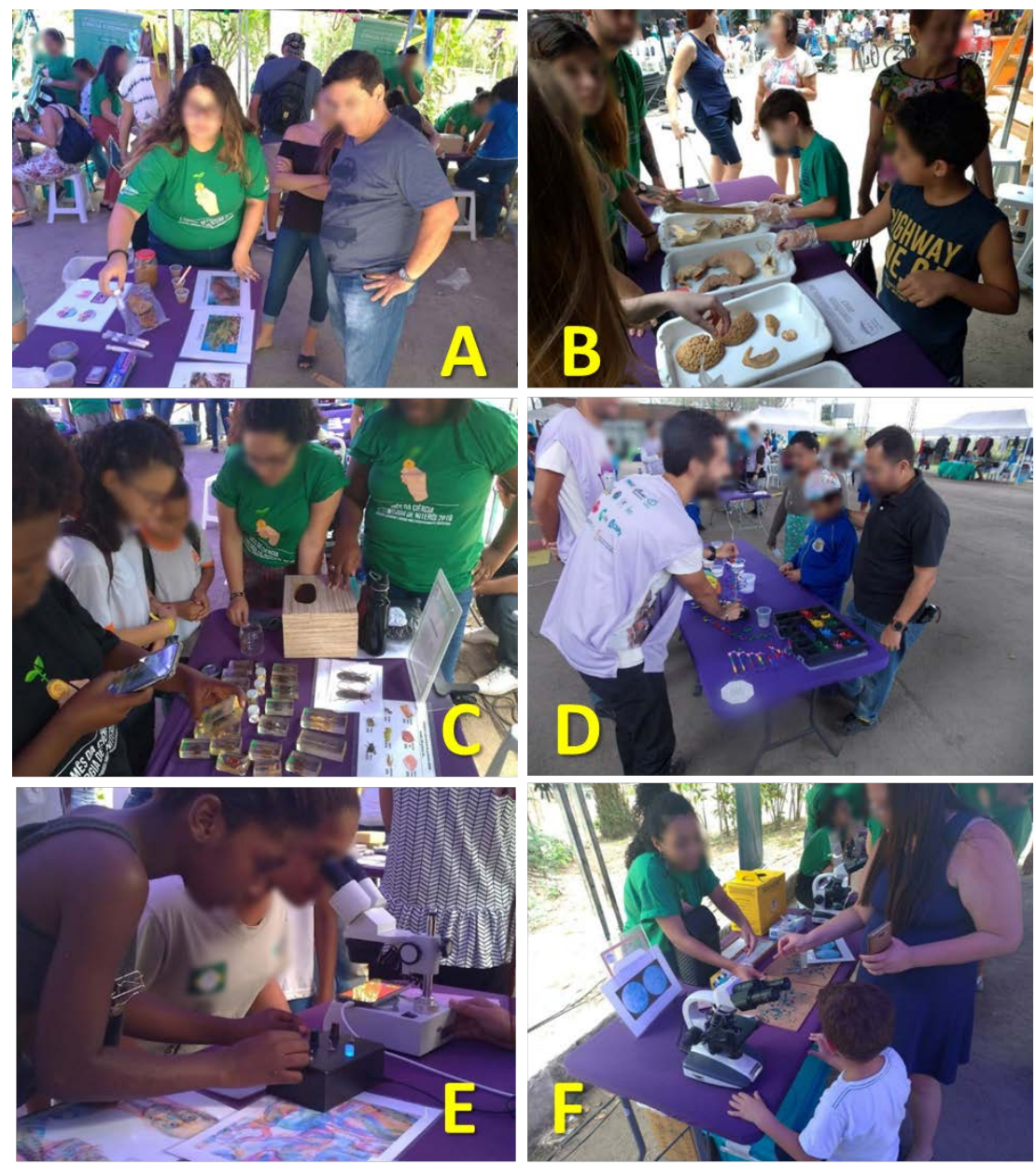

Figure 1. In all images, it is possible to observe a relationship between public, mediator and activity. In A there is a demonstration of characteristic of the coast algae of Rio de Janeiro. In B we see the public's interest in plastinated pieces. In C, it is observed as different forms of interaction with a collection of arthropods, especially a person taking a picture of one of the examples. In D it is possible to observe the assembly of DNA molecule and participation of public of different age groups at the same time. In E, it is possible to observe manipulation of the potentiometer system for composition of blue light on the LED. In F you can see a woman producing a histological slide with her cells and interaction with the mediator.

- Light Composition-A device containing a three-pole LED is used to control the intensity of Green, Red and Blue light independently, in order to observe the color that is formed from the changes made (Figure 1(E));

- Knowing your cells-Oral epithelial cells are obtained, stained by public and observed under a microscope (Figure $1(\mathrm{~F})$ );

- Curve in the laser-A green laser is used pointed to an orifice where a flow of water runs, showing that water can change the path of light beam (Figure 2(A));

- Environmental education-This is a card game in which planting needs (soil area, amount of water for irrigation and use of pesticides) for each type of food are discussed (Figure 2(B)); 

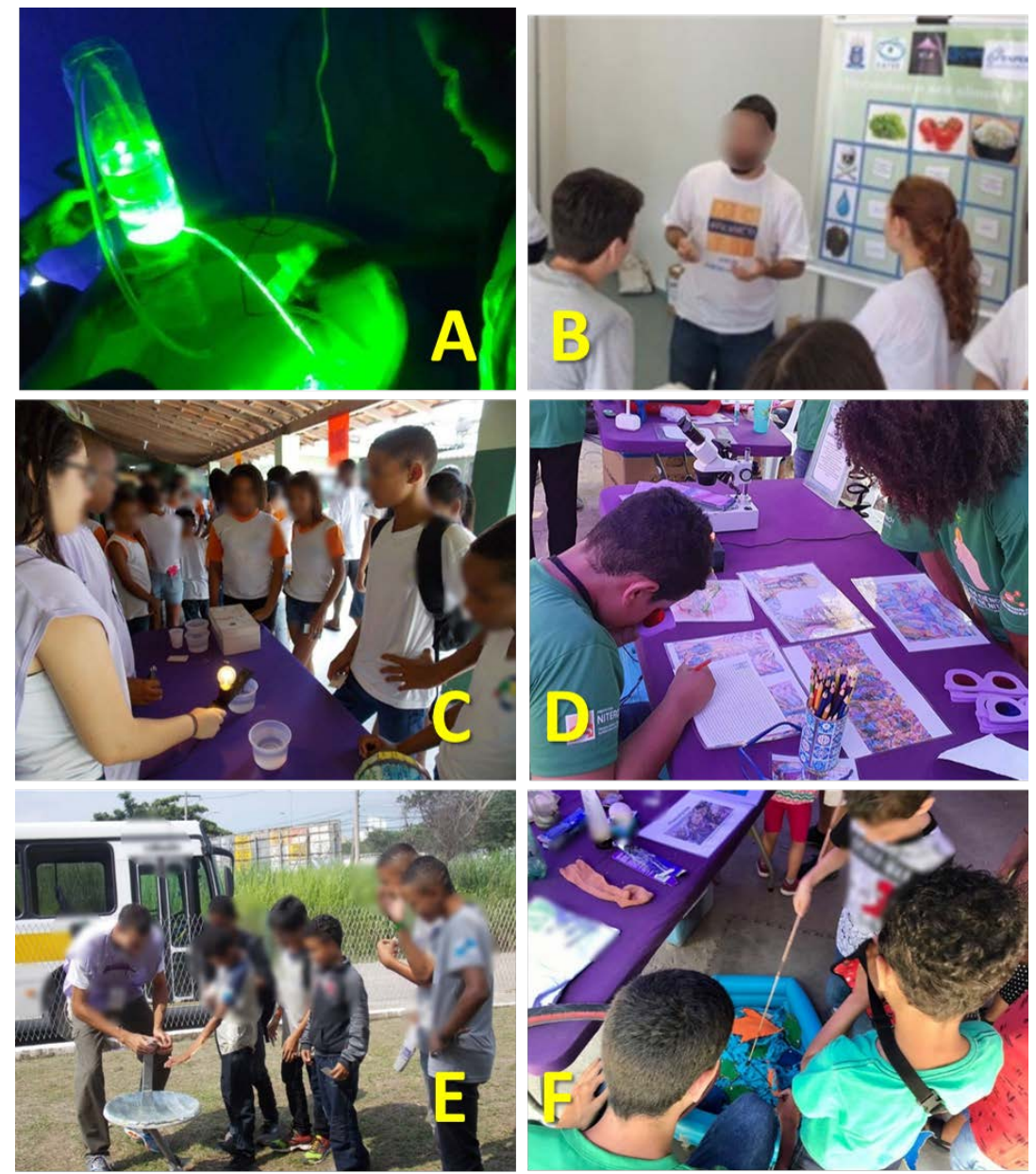

Figure 2. In all images you can see participation of the public, especially children. In A we have demonstration of laser reflection phenomenon within the water flow. In B, it is possible to note public's attention to the mediator in his dialogues on environmental education. In $\mathrm{C}$, one can observe public's attention when perceiving electrical conduction capacity on different liquids when lighting a lamp. In D, public's dedication to solving secret writing activity is evident. In E you can observe interaction of public with focal point of the solar cooker, feeling the heat that can be generated. In F, you can see children playing fishing while aspects of microplastics in nature were discussed.

- Electroconductivity-A device with an open circuit with two exposed electrodes are inserted in different liquid solutions to demonstrate their ability to conduct electricity and turn on LED and incandescent lamps (Figure 2(C));

- Secret writing-Blue and red light filters are used to observe images printed in different colors and overlaid. Also, public must write "hidden" messages on a sheet of grid paper using colors combination and message will be revealed using the correct filter (Figure 2(D));

- Solar cooker-It consists of a satellite dish coated with small mirrors demonstrating the convergence of solar rays and consequently the heat obtained at the focal point (Figure 2(E));

- Microplastic-Samples of microplastics collected in coastal regions are presented, together with samples retained of hygiene and cosmetic products 
(Figure 2(F));

- Microscopy-Histological slides from different animal tissues are presented accompanied by illustrative images of the field of view (Figure 3(A));

- Paper that sprouts-Production of handmade recycled papers filled with small vegetable seeds to discuss various topics such as recycling, creative economy, water reuse, etc (Figure 3(B));

- Water $\mathrm{pH}-$ Colorimetric tests are performed to measure $\mathrm{pH}$ of different water sources, discussing the importance of this indicator for use and conservation of water (Figure 3(C));

- Food pyramid-Representatives of all types of food, made of plastic or nonperishable materials, are presented, and the public must arrange them in a ladder-shaped pyramid with shelves, thus comparing and discussing their food routine and its possible health consequences (Figure 3(D));
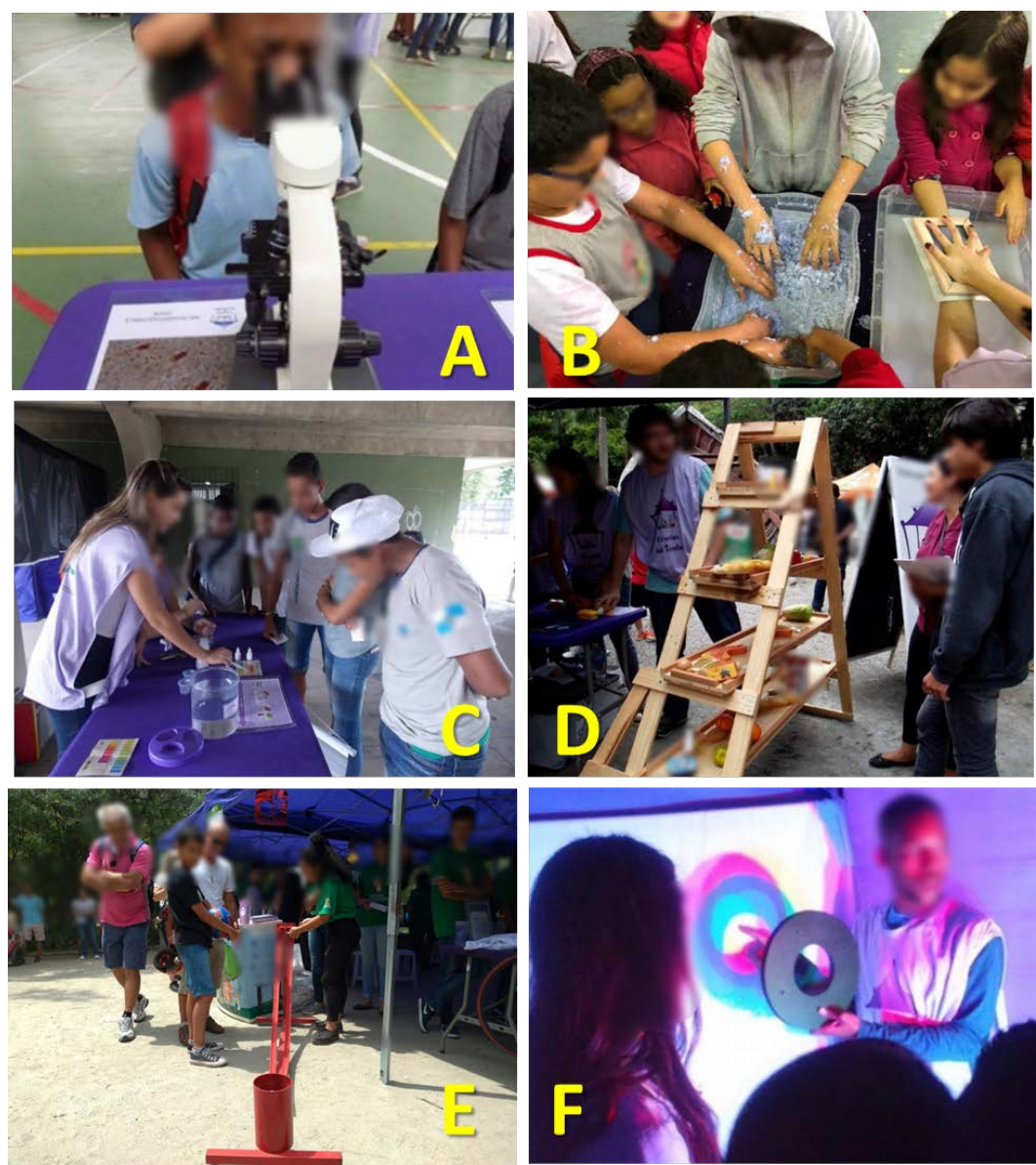

Figure 3. The images demonstrate variation of environments with exposures being carried out, either indoors ( $A, B, C$ and $F$ ) or outdoors (D and $E$ ). In A microscopy activity and its aid image for histological observation. In $\mathrm{B}$, children helping to process the dough for production of seed paper. In $\mathrm{C}$, analyzes of $\mathrm{pH}$ indicator color was observed. In $\mathrm{D}$, there was a moment of dialogue and reflection on the organization of food in food pyramid. In E you can observe adults and a child analyzing the ramp experiment. In F can be observed the mediator encouraging discussion about the effect of shadows on light composition. 
- Ramp-It is a device made up of two parallel ramps, one curved and the other straight, both starting and ending with the same parameters. Two billiard balls are placed on these ramps, which are released simultaneously and come to an end at different times. Issues of movement, friction, acceleration, among others are discussed (Figure 3(E));

- Colored shadows-Three sources of light, green, blue and red, are used in a dim environment, at the point of focus of this lighting are placed discs that highlight the phenomenon of adding color subtraction in visible light (Figure 3(F));

- Ozobot-It is a robot that follows paths designed with a marker pen, its programming is done through specific color patterns and sensors, so challenges are presented and public must overcome them (Figure 4(A));
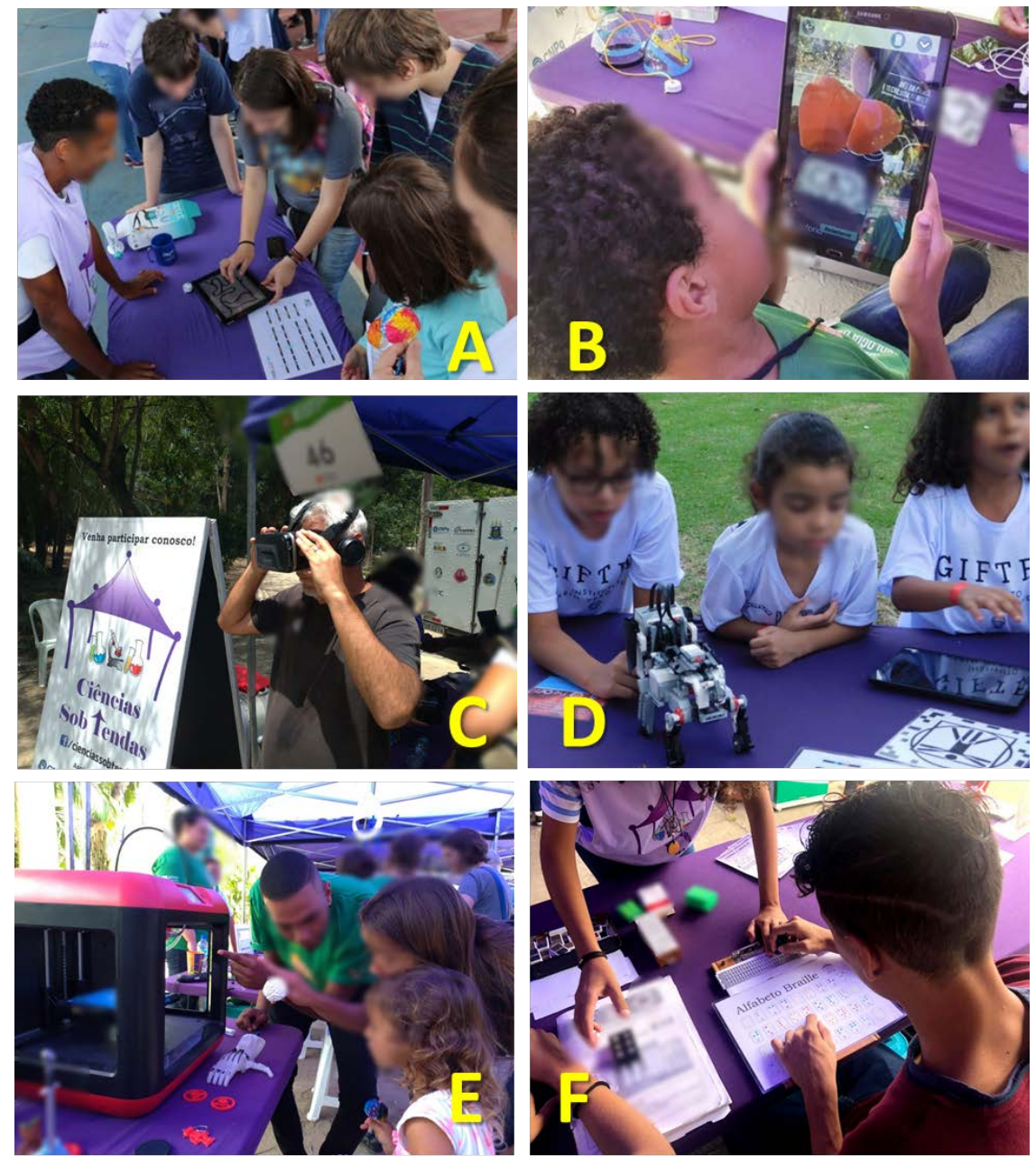

Figure 4. Images demonstrate direct interaction of the public with different technologies present in activities, whether digital or not. In A public interaction with Ozobot's challenges. In B presentation of liver in augmented reality. In C outdoor use of virtual reality experiences, even captivating the elderly. In $\mathrm{D}$, a child interacted with Lego Robot trying to understand its program logic and responses to the stimuli provided. In E it can be seen that both adult and mediator try to demonstrate operation of $3 \mathrm{D}$ printer to the child. In $\mathrm{F}$ a child learning the process of Braille writing. 
- Augmented Reality-It uses tablets and apps to present elements of augmented reality, inserting virtual elements into the image of reality, prompting discussions on various topics from health to astronomy (Figure 4(B));

- Virtual Reality-Uses virtual reality glasses with popular cell phones in order to provide a virtual immersion in different environments, from the seabed to the central nervous system (Figure 4(C));

- Lego Robot-It uses Lego Robotics Mindstorms EV3 in its various configurations and presents programming as a way to solve small problems, challenging the public to understand its functions and applications (Figure 4(D));

- 3D printing-Uses a 3D printer with PLA filament to produce various objects. The public interacted with image creation and preparation software, printing process and finished object (Figure 4(E));

- Braille-Various instruments are used for presentation and writing in the Braille system, sensitizing and informing the public about such writing (Figure $4(\mathrm{~F})$ );

- Inclusion Sidewalk-Wooden pallets are arranged to simulate a sidewalk with possible obstacles such as ramps, public telephones, garbage bags and other objects. where people can walk, being sensitized to the routine of a visually impaired person (Figure 5(A));

- Painting the body-Representations of human organs are used for painting, such as a brain-shaped helmet, a tongue to be used as a tie, a plaster brain, stimulating creative expression and discussion about the body (Figure 5(B));

- Libras-A memory game with signs from the Brazilian Sign Language and their respective graphic representations is used encouraging the public to know some signs of daily life and communication of the deaf (Figure 5(C));

- Puppet Theater-Foam puppets are used, controlling their mouth and head movement, in all there are five characters representing different ethnic groups such as a black, a blonde, an oriental, a brunette and a Caucasian. The play discuss various scientific themes interspersed with the public's daily life (Figure 5(D));

- Pantograph-This instrument is used to demonstrate the Tales Theorem and its implications for copying, reducing and enlarging images (Figure 5(E));

- Tangram-Geometric pieces are used to compose different images in the form of challenges, stimulating abstraction and identification of the geometric elements of the images (Figure 5(F)).

All activities were carried out by CST team and were motivated by the themes proposed for National Week of Science and Technology (SNCT), the largest and most important scientific communication event in Brazil. As described in Nascimento et al. (2018), such affirmative practices demonstrate the importance of this mediation strategy for strengthening of public policies aimed to science communication.

Through free interpretation analysis, it was possible to observe the activities of CST and classify them within the STEAM areas, highlighting aspects related to 

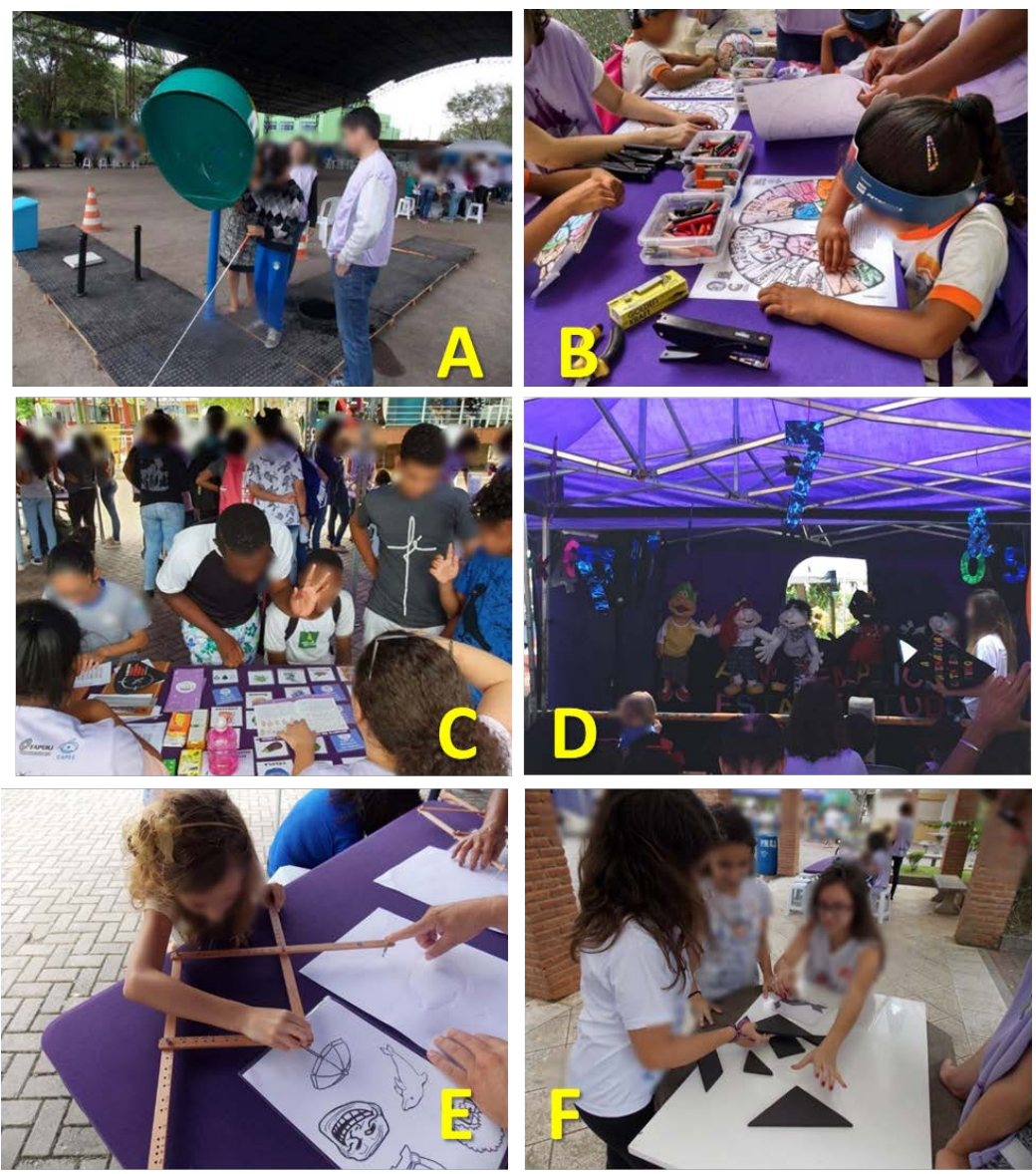

Figure 5. The images demonstrated service to children, majority of Sciences Under Tents. In $\mathrm{A}$, awareness of blindness condition was exposed in a sidewalk model with its obstacles. In $\mathrm{B}$ aesthetic and artistic expression of painting a brain that will be transformed into a helmet. In $\mathrm{C}$, dissemination and challenge of communicating through Brazilian Sign Language (LIBRAS). In D a puppet theater presentation, discussing scientific themes and representing the diversity of people in everyday life. In $\mathrm{E}$ a child using a pantograph to enlarge an image. In $\mathrm{F}$ tangram uniting girls in challenges of logic and spatial vision.

the reproducibility of each one. Therefore, Table 2 demonstrates this organization and the observations that can guide the process of reproducing activities.

It can be noted that such activities corroborate with low-cost science education and teaching practices (Beyleveldt et al., 2004; Correa et al., 2020; Hume et al., 2014; Rodrigues et al., 2016; Srinivasan et al., 2013), using materials of easy access, reusable, recycled and, even those of greater monetary investment, are of low complexity of reproducibility.

It is worth mentioning that literature presents the inclusion of Arts in STEAM as a recent movement, aiming to somehow include the humanities (Conner et al., 2017; Wang et al., 2018). However, interactions between STEAM areas are still discussed, since it is desirable that approaches must be interdisciplinary. However, arts have been presented and used commonly as a means to express the content discussed and developed in other areas (Conner et al., 2017; Shatunova et al., 2019; Wang et al., 2018; Yoon \& Choi, 2015). In the case of CST, the "A" of the 
Table 2. Classification of science under tents activities in the STEAM areas and aspects of their reproducibility.

\begin{tabular}{|c|c|}
\hline Activity & Remarks regarding reproducibility \\
\hline & STEAM-Science \\
\hline Seaweed & Limited by the availability of coastal samples \\
\hline Compared anatomy & $\begin{array}{l}\text { The production of platinum parts is expensive and human parts are } \\
\text { difficult to access. However, they can be replaced by commercial models }\end{array}$ \\
\hline Arthropods & Handicraft material is used for its production \\
\hline Biotechnology & Templates are easily produced and printed \\
\hline Light Composition & Requires little electrical knowledge and few components \\
\hline Knowing your cells & $\begin{array}{l}\text { lacks access to the microscope which can be considered a high initial } \\
\text { investment }\end{array}$ \\
\hline Laser curve & It uses materials of easy access \\
\hline \multicolumn{2}{|c|}{ environmental education Achievable with simple prints } \\
\hline Electroconductivity & Built with materials easily accessible in the construction house \\
\hline Secret writing & $\begin{array}{l}\text { Its limitation is the access to the gelatin film that is used to compose the } \\
\text { light filter }\end{array}$ \\
\hline Solar cooker & Built with reused material \\
\hline Microplastic & Lacks fine sieves to obtain samples \\
\hline Microscopy & $\begin{array}{l}\text { Lacks access to the microscope which can be considered a high initial } \\
\text { investment }\end{array}$ \\
\hline Paper that sprouts & Made with household appliances and recyclable paper. \\
\hline Water $\mathrm{pH}$ & $\begin{array}{l}\text { Greater complexity in finding the } \mathrm{pH} \text { indicator substances, but available } \\
\text { at swimming pool supply stores }\end{array}$ \\
\hline Food pyramid & Made with reused wood, toys and decorative food within easy reach \\
\hline Ramp & $\begin{array}{l}\text { acks specific production so that the start parameters are isonomic and } \\
\text { the result is reliable }\end{array}$ \\
\hline Colored shadows & Built with materials easily accessible in the construction house \\
\hline \multicolumn{2}{|r|}{ STEAM-Technology } \\
\hline Ozobot & lacks access to Ozobot which can be considered a high initial investment \\
\hline Augmented Reality & Lacks tablets or smartphones \\
\hline Virtual reality & $\begin{array}{l}\text { Lacks smartphones and virtual reality glasses, the latter being able to be } \\
\text { made from cardboard models }\end{array}$ \\
\hline Lego Robot & $\begin{array}{l}\text { lacks access to Lego Robotics Mindstorms EV3 which can be considered } \\
\text { a high initial investment }\end{array}$ \\
\hline \multicolumn{2}{|r|}{ STEAM-Engineering } \\
\hline $3 \mathrm{D}$ printer & $\begin{array}{l}\text { It lacks access to a } 3 \mathrm{D} \text { printer which can be considered a high initial } \\
\text { investment. }\end{array}$ \\
\hline \multicolumn{2}{|r|}{ STEAM-Arts } \\
\hline Braille & $\begin{array}{l}\text { Specific materials are used for Braille writing, available in stationery } \\
\text { stores and school supply stores. }\end{array}$ \\
\hline Sidewalk of Inclusion & Reused material, obtained in several locations. \\
\hline
\end{tabular}


Continued

\begin{tabular}{|c|c|}
\hline Libras & Material printed on handling-resistant paper \\
\hline Body painting & Printed material and use of brain-shaped silicone shapes \\
\hline Puppet Theater & $\begin{array}{l}\text { Access to puppets and scenery structure, can be done with reusable } \\
\text { material }\end{array}$ \\
\hline \multicolumn{2}{|r|}{ STEAM-Mathematics } \\
\hline Pantograph & $\begin{array}{l}\text { Can be purchased at a school supply store or made using } 40 \mathrm{~cm} \text { rulers } \\
\text { and screws }\end{array}$ \\
\hline Tangram & $\begin{array}{l}\text { It can be purchased at a school supply store or made using different flat } \\
\text { materials (cardboard, cardboard, EVA, etc.) }\end{array}$ \\
\hline
\end{tabular}

arts is developed in a wide spectrum: the puppet show, despite addressing science themes, have script, composition and artistic production that are worked on by the CST team; The inclusive activities Braile, LIBRAS and Sidewalk of Inclusion present, above all, the objective of raising awareness for inclusion and thus use themes and approaches that involve all areas of STEAM and mainly humanities; The activity Painting the body stimulates as much motor and creative skills as knowledge about structures of human body. Thus, CST exhibition not only develops the "A" of STEAM but also integrates it in an interdisciplinary way, as recommended by methodology (Yoon \& Choi, 2015).

In addition to the activities, we also analyzed mediators and their role for the public attendance process. For this, it was possible to have access to information about the mediators who are part of the CST team. Such data are relevant to understand who this audience is and how they can interfere in the science communication process developed by CST.

Most of the mediators were female (approximately 64\% of the scholarship holders and $77.8 \%$ of the volunteers, $\mathrm{n}=88$ ), were mostly in the age group of 19 to 27 years old, with the highest number at 21 years and were, in general, from courses of biological field.

We believe that this profile is justified since the headquarters of CST is located on a university campus dedicated to biological areas, which in Brazil are courses composed of a female majority (Oliveira \& Fernandes, 2016). This profile demonstrates that CST's mediators strengthen the idea of women and girls in the sciences, which are motivation for many of children and the public that participated in the exhibitions, reinforcing aspects of gender equality and female empowerment set out in the SDG 5-Gender equality (ONU, 2015).

In addition, mediators' age range is within what is expected for the university audience, from 19 years old with predominance between 19 and 25 years old. We found a prevalence of mediators at 21 years of age (22\%). We believe that this profile represents undergraduates who are close to the end of their course, when they have more hours for academic activities outside the classroom (MEC/INEP, 2017).

When we analyzed the areas of training of mediators, it was possible to verify that they had origins in almost all areas of STEAM (Anisimova, Shatunova, \& 
Sabirova, 2018; Conner et al., 2017; Shatunova et al., 2019; Wang et al., 2018), except for the area of engineering. The most representative area was science (71.9\%) with graduation courses in Biology (32.6\%), Biomedicine (20.2\%), Veterinary (5.6\%), Pharmacy (4.5\%), Chemistry (2.2\%), Physics (3.4\%), Medicine (1.1\%), Nutrition (1.1\%) and Nursing (1.1\%); humanities areas (12.3\%) with graduation courses in Arts (2.2\%), Letters (1.1\%), Pedagogy (3.4\%) and Cultural Production (6.7\%); Mathematics with degrees in statistics $(2.2 \%)$ and mathematics (3.4\%); and Technological with degrees in computer science (1.1\%). The other courses that were not included in the STEAM areas (administration, law, international relations), despite being humanities areas and having unquestionable importance in society, are not yet included in the STEAM education practices.

The post-graduation courses were grouped without explaining their origin and research focus, therefore, they were disregarded from our disciplinary classification. However, postgraduate research plays a fundamental role for STEAM, as it places the learner in the position of builder of knowledge and the search for solutions for society (Wang et al., 2018). Thus, the participation of mediators from postgraduate courses confirms the relationship between public, exhibition and practices of STEAM.

We can observe interdisciplinarity in processes and in the development of experiences and interactions with the public during activities presented and described above. However the mediator is the articulating and stimulating agent of interdisciplinarity (Alves, 2016; Alves et al., 2019; Carlétti \& Massarani 2015; Nascimento et al., 2018; Paula, 2017). It was possible to observe that in several moments, mediation leads to construction of knowledge about the experiences lived by the public. For example, in the activity of the solar cooker there were discussions about the properties of physics, but biological aspects such as photosynthesis, social aspects such as the importance of this system for economically deprived regions and even for energy generation were also discussed. There are countless reports that could be explained for each of described activities. However, it is the diversity of undergraduate courses, experiences, knowledge and experiences of the mediators that bring the richness and interdisciplinarity of dialogues with the public.

From the documentary analysis, it was possible to identify that the activities under the Sciences Under Tents (CST) started in 2013 with the support of the Carlos Chagas Filho Foundation for Research Support in the State of Rio de Janeiro (FAPERJ) (Alves et al., 2019), and until 2019 funds were raised in the order of 310 thousand reais, approximately 72 thousand dollars ${ }^{2}$. All funding came from public agencies that promote education, science and technology, such as the National Council for Scientific and Technological Development (CNPq), the Coordination for the Improvement of Higher Education Personnel (CAPES), the Ministry of Education of Brazil and FAPERJ.

${ }^{2}$ All currency conversions from real to dollar were made using the dollar value on 2/7/2020 — (Brazil, 2020). 
Much of this period was under the influence of a policy to encourage scientific and technological development in the country, a historic period that certainly expanded the development of actions aimed at science education, especially to expand science communication (Ferreira, 2014). After 2016, resources became scarcer due to the Brazilian economic crisis, which has worsened until the writing of this article and which tends to be even worse with the post-pandemic economic forecasts of Covid-19 (Klebis, 2018).

Fluminense Federal University, in addition to providing all administrative infrastructure for the maintenance of the CST, also finances it from annual grant of extension scholarships, which are allocated to students of this institution in order to assist in the maintenance and execution of the CST and associated projects. Since 2013, these resources have totaled 162 thousand reais, approximately 37 thousand dollars.

Human resources are an integral and fundamental part of several educational actions and models. Despite the STEAM model, although promoting student autonomy, it also lacks tutors and mediators to guide discussions and development of learning process. In addition, the reality of science centers and museums in Brazil indicates the strong presence of mediators and their attributions in these spaces are varied, placing them in an essential condition for the proper functioning of these spaces (Carlétti \& Massarani, 2015).

In addition to such incentives granted directly to the CST and which were under its management, food counterpart of the team of mediators must be incorporated into financing. This cost of food is responsibility of exhibition host institutions. For this purpose, two snacks (one in the morning and one in the afternoon) and lunch are considered. Thus, it can be estimated that approximately 60 thousand reais, approximately 14 thousand dollars, were invested in food. This counterpart was necessary since the Brazilian legislation on public support for the scientific and technology projects does not allow the use of resources for acquisition or supply of food of any kind, regardless of the situation or nature of the projects financed (Brazil, 2019).

Altogether, it can be considered that over six years of uninterrupted activities, CST raised global resources in the order of 530 thousand reais, approximately 125 thousand dollars. This resource was intended to serve attended public, which according to the internal reports of CST, consisted of approximately 45 thousand people distributed in 25 cities in the State of Rio de Janeiro (Alves, 2016; Alves et al., 2019; Pereira et al., 2018). Thus, it is possible to correlate that for each person served, approximately $\mathrm{R} \$ 11.80$ (approximately US\$2.75) was invested, thus characterizing a low-cost scientific exhibition, with access to regions and people with the greatest difficulties in experiencing STEAM methodology in center and science museums.

According to the Organization for Economic Cooperation and Development (OECD, 2019) the average investment in basic education in Brazil, per student per year is US\$3.867. This represents about US\$19.33 per day, considering 200 school days in the year, with a daily workload of five hours (Brazil, 2018). 
Therefore, the CST exhibition, which attends public for the same period of time, costs about $14 \%$ of the estimated value for Brazilian investment in basic education. Considering the average investment in basic education in OECD member countries of US $\$ 9,600.00$, CST represents an investment of approximately $5.7 \%$ of total investment in education. The low-cost relationship for actions of this type favors SDG 10_-"Reducing inequalities", as it allows such experiences to be potentially applied in different realities, in addition to being inclusive, democratic and accessible to all (ONU, 2015).

The investment in formal education, registered by OECD, compares to the investment made by CST as a representative of non-formal education in science centers and museums and for that, despite their differences in pedagogical strategies and objectives, they are comparable over time that the student/audience dedicates to educational experiences. It is noteworthy that even without having comparative parameters to content learning, experiences in non-formal education environments can positively influence the learning process (Paula, 2017; Paula, Pereira, \& Coutinho-Silva, 2019).

Thus, it can be considered that CST is a low-cost strategy for communicating science in places that do not have museums or a science center and that this type of public policy must be continued, whether with public or private resources, corroborating with Norberto \& Marandino (2017).

In summary, CST's exposure to low cost per capita can be considered a reality that meets SDGs 4, 5 and 10. Low-cost scientific activities can expand the offer, distribute better and more learning opportunities and, when considering the popular character of the exhibition-all audiences, regardless of gender, skin color, socioeconomic status-all have access to the same type of experience and attention as mediators (Beyleveldt et al., 2004; Correa et al., 2020; Hume et al., 2014; Rodrigues et al., 2016; Srinivasan et al., 2013).

Considering the low cost investment it is important to analyze how the public perceives and feels when participating in the exhibition. To this end, data from Elysio \& colleagues (2016) research about CST's exhibitions were re-analyzed.

The questions presented in Table 3 deal with different aspects of public's relationship with CST. The questions sought to identify motivation and satisfaction regarding to exhibition. The questions "Did you find what you saw at CST interesting?", "Would you like to participate in more events like CST?" and "Would you recommend other people to participate in events like CST?" are involved with aspects of satisfaction, as initially presented by Elysio \& colleagues (2016). The questions "Did you learn anything new?" and "Are you curious to know more about science?" can be related to motivation in STEAM themes exposed at CST's activities. In this way, positive responses are indicative that the CST is well accepted by its audience. In addition, it is emphasized that negative responses are also relevant as they can guide innovations in the exhibition so that it can be better accepted by audiences of different age groups, especially those between 21 and 25 years old. 
Table 3. Perception of the visiting public of sciences under tents about the science communication developed.

\begin{tabular}{|c|c|c|c|c|c|c|c|c|c|c|c|}
\hline & & \multicolumn{2}{|c|}{$\begin{array}{l}\text { Did you find what you } \\
\text { saw at CST interesting? }\end{array}$} & \multicolumn{2}{|c|}{$\begin{array}{l}\text { Would you like to } \\
\text { participate in more } \\
\text { events like CST? }\end{array}$} & \multicolumn{2}{|c|}{$\begin{array}{l}\text { Did you learn } \\
\text { anything new? }\end{array}$} & \multicolumn{2}{|c|}{$\begin{array}{l}\text { Would you recommend } \\
\text { other people to participate } \\
\text { in events like CST? }\end{array}$} & \multicolumn{2}{|c|}{$\begin{array}{c}\text { Are you curious to } \\
\text { know more about } \\
\text { science? }\end{array}$} \\
\hline & & Yes & No & Yes & No & Yes & No & Yes & No & Yes & No \\
\hline \multirow{6}{*}{ 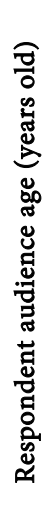 } & $\begin{array}{c}0-5 \\
\mathrm{n}=26\end{array}$ & 88.5 & 11.5 & 84.6 & 15.4 & 95.2 & 4.8 & 92.3 & 7.7 & 92.3 & 7.7 \\
\hline & $\begin{array}{c}6-10 \\
n=134\end{array}$ & 99.2 & 0.8 & 100.0 & 0.0 & 96.9 & 3.1 & 93.1 & 6.9 & 96.1 & 3.9 \\
\hline & $\begin{array}{l}11-15 \\
\mathrm{n}=309\end{array}$ & 97.0 & 3.0 & 94.3 & 5.7 & 96.9 & 3.1 & 95.6 & 4.4 & 96.8 & 3.2 \\
\hline & $\begin{array}{l}16-20 \\
\mathrm{n}=109\end{array}$ & 98.2 & 1.8 & 98.1 & 1.9 & 98.1 & 1.9 & 98.1 & 1.9 & 97.0 & 3.0 \\
\hline & $\begin{array}{l}21-25 \\
\mathrm{n}=14\end{array}$ & 78.6 & 21.4 & 92.9 & 7.1 & 91.7 & 8.3 & 92.3 & 7.7 & 85.7 & 14.3 \\
\hline & $\begin{array}{c}>26 \\
\mathrm{n}=58\end{array}$ & 96.5 & 3.5 & 94.8 & 5.2 & 100.0 & 0.0 & 96.5 & 3.5 & 100.0 & 0.0 \\
\hline \multicolumn{2}{|c|}{$\begin{array}{l}\text { Average } \\
\mathrm{n}=650\end{array}$} & 93.0 & 7.0 & 94.1 & 5.9 & 96.5 & 3.5 & 94.7 & 5.3 & 94.7 & 5.3 \\
\hline
\end{tabular}

All values expressed as a percentage (\%). Source: (ELYSIO et al., 2016).

As shown in Table 3, it was possible to identify that the majority of the public attended was satisfied with the exposure, explaining an average of more than $90 \%$ of positive responses in all questions analyzed. These data reflect that despite the low cost invested, the exhibition received a positive perception from the public. This factor is preponderant with regard to interest and learning opportunities. Such action meets the premises of STEAM, which the apprentice must be motivated, especially to the challenges and demands of his daily life, in addition to reinforcing that science centers and museums are also spaces for STEAM education to develop (Anderson \& Jiao, 2017; Yoon \& Choi, 2015).

\section{Conclusion}

The scientific exhibition of Sciences Under Tents has potential to cover SDGs 4, 5 and 10, being in synergy with the prerogatives of equal opportunities, valuing education, especially women, providing opportunities for dialogues for sustainable development and income generation. However, is necessary more research to confirm this.

In addition, it was possible to verify that the exhibition is well accepted by the public and that satisfaction with it is high in different age groups of the public served. This demonstrates that, within its organization and execution, the CST is well evaluated and accepted by the public.

This acceptance is a reflection of the activities and mediation present in the exhibition, since its challenging, experimental and interdisciplinary approach stimulates the interaction between the public and the exhibition in addition to strengthening the relationship of STEAM education in an environment outside the classroom. 
All of this is carried out with minimal budgets, being estimated at less than three dollars per person and free of charge for the population that receives it and can certainly be exported to other realities in the world.

Considering all the aspects presented and the prospects for a post-pandemic world of Covid-19, systematizing STEAM education actions at low cost will become an opportunity to resume social and economic growth, valuing the 2030 agenda and helping in the formation of a new generation of global.

\section{Acknowledgements}

This work was conducted during a research fellowship supported by National Council for Scientific and Technological Development (CNPq), Carlos Chagas Filho Foundation for Research Support of Rio de Janeiro State (FAPERJ) and was also financed in part by Coordenação de Aperfeiçoamento de Pessoal de Nível Superior-Brasil (CAPES)—Finance Code 001, and Extension Scholarship Program-Dean of Extension/PROEX-UFF.

\section{Conflicts of Interest}

The authors declare no conflicts of interest regarding the publication of this paper.

\section{References}

Almeida, C., Bento, L., Jardim, G., Freire, M., Amorim, L., \& Ramalho, M. (2018). Ciência e Teatro Como Objeto de Pesquisa. Ciência e Cultura, 70, 35-40. https://doi.org/10.21800/2317-66602018000200011

Almeida, C., Brito, F., Ferreira, J. R., Massarani, L., \& Amorim, L. (2015). Centros e Museus de Ciência Do Brasil 2015. Rio de Janeiro: Associação Brasileira de Centros e Museus de Ciência, UFRJ.

http://www.museudavida.fiocruz.br/images/Publicacoes_Educacao/PDFs/centrosemus eusdecienciadobrasil2015novaversao.pdf

Alves, G. H. (2016). Ciências Sob Tendas-Despertando Para a Biotecnologia. Universidade Federal Fluminense.

https://sucupira.capes.gov.br/sucupira/public/consultas/coleta/trabalhoConclusao/view TrabalhoConclusao.jsf?popup $=$ true\&id_trabalho $=4252291$

Alves, G. H. V. S., Marins, M. M., Pereira, G. R., \& Fragel-Madeira, L. (2019). Ciências Sob Tendas Levando a Extensão Ainda Mais Longe. In Educação em Ciências, Saúde e Extensão universitária (p. 11). Curitiba: Brazil Publishing.

Anderson, D., \& Jiao, J. (2017). International Dialogue on the Role of Museum Education in STEM and STEAM Education. Journal of East China Normal University (Educational Sciences), 35, 122. http://xbjk.ecnu.edu.cn/EN/10.16382/j.cnki.1000-5560.2017.04.013

Angrosino, M. (2009). Etnografia e Observação Participante. in Etnografia e Observação Participante.

Anisimova, T. I., Shatunova, O. V., \& Sabirova, F. M. (2018). STEAM-Education as Innovative Technology for Industry 4.0. Nauchnyy Dialog, 11, 322-332.

https://doi.org/10.24224/2227-1295-2018-11-322-332 
Anjos, M. B., Rôças, G., \& Pereira, M. V. (2019). Análise de Livre Interpretação Como Uma Possibilidade de Caminho Metodológico. Ensino, Saude e Ambiente, 12, 27-39. https://periodicos.uff.br/ensinosaudeambiente/article/view/29108

Araújo-Jorge, T. C. de, Sawada, A., Rocha, R. C. M., Azevedo, S. M. G., Ribeiro, J. M., Matraca, M. V. C., Borges, C. A. X., Sheila, S., Fortuna, D. B., Barros, M. D. M., Mendes, M. O., Garzoni, L. R., de la Rocque, L., Meirelles, R. M. S., Trajano, V. S., \&

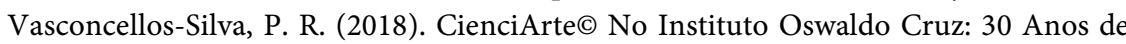
Experiências $\mathrm{Na}$ Construção de Um Conceito Interdisciplinar. Ciência e Cultura, 70, 25-34. https://doi.org/10.21800/2317-66602018000200010

Beyleveldt, J. S., Burnett, C., \& Hollander, W. J. (2004). Health-Related Knowledge and Behaviour of Primary School Children. African Journal for Physical, Health Education, Recreation and Dance, 9, 357-371. https://doi.org/10.4314/ajpherd.v9i3.24651

Brazil (2018). Base Nacional Comum Curricular.

Brazil (2019). Chamada MCTIC/CNPq 09/2019_Semana Nacional de Ciência e Tecnologia 2019.

Brazil, Ipeadata (2020). Ipeadata-Taxa de Câmbio Comercial Para Compra: Real (R\$)/Dólar Americano (US\$).

http://www.ipeadata.gov.br/ExibeSerie.aspx?serid=38590\&module $=M$

Brito, F., Ferreira, J. R., \& Massarani, L. (2005). Centros e Museus de Ciências Do Brasil. Rio de Janeiro: ABCMC: UFRJ, Casa Da Ciência: FIOCRUZ, Museu Da Vida. http://www.museudavida.fiocruz.br/images/Publicacoes_Educacao/PDFs/GuiaMuseus deCiencia2005.pdf

Carlétti, C., \& Massarani, L. (2015). Mediadores de Centros e Museus de Ciência: Um Estudo Sobre Quem São Estes Atores-Chave Na Mediação Entre a Ciência e o Público No Brasil. Journal of Science Communication, 14, 1-17. https://jcom.sissa.it/sites/default/files/documents/JCOM_1402_2015_A01_pt.pdf

Cazelli, S., Falcão, D., \& Valente, M. E. (2018). Visita Estimulada e Empoderamento: Por Um Museu Menos Excludente. Caderno Virtual de Turismo, 18, 66-84. https://doi.org/10.18472/cvt.18n1.2018.1488

Conner, L. D. C., Tzou, C., Tsurusaki, B. K., Guthrie, M., Pompea, S., \& Teal-Sullivan, P. (2017). Designing STEAM for Broad Participation in Science. Creative Education, 8, 2222-2231. https://doi.org/10.4236/ce.2017.814152

Correa, R. P., Teixeira, P. P., da Costa Lacerda, A., Rumjanek, J. B. D., Rumjanek, V. M. B. D., Cardoso, F. S., Madeira, L. F., \& Castro, H. C. (2020). Cardboard Dinosaur: The Use of Simple Three-Dimensionality and Macroscopy Tools as a Low-Cost Strategy for Presentation of Classical Biological Themes. Creative Education, 11, 250-261. https://doi.org/10.4236/ce.2020.113019

Elysio, M. S., Alves, G. H. V. S., \& Fragel-Madeira, L. (2016). A Itinerância e a Disseminação Científica: Relato Do Projeto Ciências Sob Tendas. Universidade Federal Fluminense.

Ferreira, J. R. (2014). Popularização Da Ciência e as Políticas Públicas No Brasil (2003-2012). Rio de Janeiro: Universidade Federal do Rio de Janeiro. http://www.fiocruz.br/brasiliana/media/TesedeJoseRibamarFerreira_Biofisica_UFRJ_2 014.pdf

Fontoura, H. A. da. (2011). Tematização como proposta de análise de dados na pesquisa qualitativa. In Formação de professores e diversidades culturais: Múltiplos olhares em pesquisa (pp. 61-82). Niterói: Intertexto.

Géra, Á. da S., Amado, M. V., Bittencourt, A., \& Stefanon (2017). Contribuições Da Técnica de Plastinação Para a Cultura Científica. In Florianópolis: XI Encontro Nacional de Pesquisa em Educação em Ciências (p. 8). Florianópolis, SC, Brazil.

http://www.abrapecnet.org.br/enpec/xi-enpec/anais/resumos/R2315-1.pdf 
Hume, A., Wetten, A., Feeney, C., Taylor, S., O’Dea, K., \& Brimblecombe, J. (2014). Remote School Gardens: Exploring a Cost-Effective and Novel Way to Engage Australian Indigenous Students in Nutrition and Health. Australian and New Zealand Journal of Public Health, 38, 235-240. https://doi.org/10.1111/1753-6405.12236

Klebis, D. E. (2018). Ciência Não é Gasto, é Investimento. Jornal Da Ciência. http://www.sbpcacervodigital.org.br/bitstream/20.500.11832/2993/1/JCiencia_782_web.pdf

Loureiro, M. L. de N. M. (2009). Divulgação Científica Em Museus: As Coleções e Seu Papel Na Linguagem Expográfica. Actas Do I Seminário de Investigação Em Museologia Dos Países de Língua Portuguesa e Espanhola, I, 2, 207-215. https://ler.letras.up.pt/uploads/ficheiros/8197.pdf

Massarani, L., Brito, J. R., \& Ferreira, E. F. (2009). Centros e Museus de Ciência Do Brasil 2009. Rio de Janeiro: ABCMC, Casa Da Ciência/UFRJ e Museu Da Vida/Fiocruz. http://www.museudavida.fiocruz.br/images/Publicacoes_Educacao/PDFs/GuiaCentros eMuseusdeCiencia2009.pdf

McManus, P. M. (1992). Topics in Museums and Science Education. Studies in Science Education, 20, 157-182. https://doi.org/10.1080/03057269208560007

MEC/INEP (2017). Resumo Técnico Do Censo Da Educação Superior 2017 Diretoria de Estatísticas Educacionais DEED.

http://portal.inep.gov.br/documents/186968/484154/Resumo+T\%C3\%A9cnico+Censo +da+Educa\%C3\%A7\%C3\%A3o+Superior+2017/ce993bae-3502-4098-a9aa-39b607d20 161 ?version $=1.0 \&$ download $=$ true

Murriello, S., Contier, D., \& Knobel, M. (2018). Challenges of an Exhibit on Nanoscience and Nanotechnology. Journal of Science Communication, 5, A01. https://doi.org/10.22323/2.05040201

Nascimento, A. A., Fragel-madeira, L., \& Alves, G. H. (2018). Práticas Afirmativas Da Semana Nacional de Ciências e Tecnologia No Ciências Sob Tendas. In IEncontro Nacional sobre Práticas Educativas em Museus e Centros de Ciência e Tecnologia-ENPEM Museu de Astronomia e Ciências Afins (p. 115). Rio de Janeiro, RJ, Brazil.

https://docplayer.com.br/151800032-Cnpq-conselho-nacional-de-desenvolvimento-cie ntifico-e-tecnologico-samn-associacao-amigos-do-museu-nacional.html

Norberto Rocha, J., \& Marandino, M. (2017). Mobile Science Museums and Centres and Their History in the Public Communication of Science. JCOM, 16, A04.

https://doi.org/10.22323/2.16030204

OECD (2019). Education at a Glance 2019: OECD Indicators-Brazil. Organisation for Economic Co-Operation and Development. https://doi.org/10.1787/f8d7880d-en https://www.oecd-ilibrary.org/education/education-at-a-glance-2019_246ea76d-en

Oliveira, M. A., \& Fernandes, M. C. S. G. (2016). A Atividade Discente Na Universidade: Caracterização Dos Estudantes e Impactos Da Produtividade Acadêmica. Revista Ibero-Americana de Estudos Em Educação, 11, 1423-1440.

https://doi.org/10.21723/riaee.v11.n3.7179

ONU, Brasil (2015). Transformando Nosso Mundo: A Agenda 2030 Para o Desenvolvimento Sustentável.

https://nacoesunidas.org/wp-content/uploads/2015/10/agenda2030-pt-br.pdf

Oppenheimer, F. (1972). The Exploratorium: A Playful Museum Combines Perception and Art in Science Education. American Journal of Physics, 40, 978-984.

https://doi.org/10.1119/1.1986726

Paula, L. M. de, Pereira, G. R., \& Coutinho-Silva, R. (2019). A Função Social Dos Museus e Centros de Ciências: Integração Com Escolas e Secretarias de Educação. Ciência e Cultura, 71, 4-5. https://doi.org/10.21800/2317-66602019000200002 
Paula, L. M. de. (2017). Para além do apertar botões: A função social dos museus participativos de ciências. Rio de Janeiro: Instituto Oswaldo Cruz.

Pereira, M. L. O. V. C., Alves, G. H. V. S., Santos, R. F. d., Rodrigues, M. C. d. S., Santos, P. G. G. d., Neves, M. E. A. da C., Marins, M. M., Zeca, T. O., Almeida, H. C. C. C. de, \& Madeira, L. F. (2018). Realidade Aumentada Incorporada à Modelos Anatômicos: Uma Experiência Dentro Do Ciências Sob Tendas. SemExt-UFF. http://www.proex.uff.br/semext/anteriores/2018/TrabPDF/Trab_335.pdf

Pugh, K. J., \& Girod, M. (2007). Science, Art, and Experience: Constructing a Science Pedagogy from Dewey's Aesthetics. Journal of Science Teacher Education, 18, 9-27. https://doi.org/10.1007/s10972-006-9029-0

Rocha, C., \& Venturelli, S. (2018). Engenhando Nosso Futuro: Arte e Sociedade. Ciência e Cultura, 70, 41-46. https://doi.org/10.21800/2317-66602018000200012

Rodrigues, M., Marques, M. B., \& Carvalho, P. S. (2016). How to Build a Low Cost Spectrometer with Tracker for Teaching Light Spectra. Physics Education, 51, Article ID: 014002. https://doi.org/10.1088/0031-9120/51/1/014002

Shatunova, O., Anisimova, T., Sabirova, F., \& Kalimullina, O. (2019). STEAM as an Innovative Educational Technology. Journal of Social Studies Education Research, 10, 131-144. https://jsser.org/index.php/jsser/article/view/916

Silveira, J. R. A. da, Malina, R. F., \& Lannes, D. (2018). Arteciência: Um Retrato Acadêmico Brasileiro. Ciência e Cultura, 70, 46-55. https://doi.org/10.21800/2317-66602018000200013

Silveira, J. R. A. da. (2018). Arte e Ciência: Uma Reconexão Entre as Áreas. Ciência e Cultura, 70, 23-25. https://doi.org/10.21800/2317-66602018000200009

Srinivasan, M., Anand, B., Antony Venus, A. J., Victor, A. N., Narayanan, M., Sree Rakshaa, S. P., \& Vijayaraghavan, V. (2013). GreenEduComp: Low Cost Green Computing System for Education in Rural India: A Scheme for Sustainable Development through Education. In Proceedings of the 3rd IEEE Global Humanitarian Technology Conference (pp. 102-107). San Jose, CA, USA. https://doi.org/10.1109/GHTC.2013.6713663

UN (2020). Monthly Briefing: COVID-19 Disrupting Lives, Economies and Societies, Department of Economic and Social Affairs. https://www.un.org/development/desa/dpad/publication/world-economic-situation-an d-prospects-april-2020-briefing-no-136

Wagensberg, J. (2001). Principios Fundamentales de La Museología Científica Moderna. Cuaderno Central, 55, 22-24.

http://www.bcn.cat/publicacions/bmm/quadern_central/bmm55/5.Wagensberg.pdf

Wang, X. W., Xu, W. W., \& Guo, L. (2018). The Status Quo and Ways of STEAM Education Promoting China's Future Social Sustainable Development. Sustainability, 10, 4417. https://doi.org/10.3390/su10124417

Yoon, Y.-D., \& Choi, H. (2015). A Study on Role of Science Museum for STEAM Education. Journal of the Korea Institute of Information and Communication Engineering 19, 1353-1358. https://doi.org/10.6109/jkiice.2015.19.6.1353 